\title{
Cepat Rambat Bunyi di Udara Pada Variasi Suhu Dengan Memanfaatkan Sensor Suara Berbantuan Logger Pro dan Audacity
}

\author{
Nur Ikhwan*, Dr. Yudhiakto Pramudya \\ Program Magister Pendidikan Fisika Universitas Ahmad Dahlan \\ Jl. Pramuka 42, Sidikan, Umbulharjo, Yogyakarta 55161 \\ *Penulis Penanggungjawab E-mail : ramzynurikhwan@gmail.com \\ 085742067859
}

\begin{abstract}
ABSTRAK
Pada pokok bahasan bunyi khususnya dalam eksperimen cepat rambat bunyi, umumnya yang digunakan pada suhu $25^{\circ} \mathrm{C}$ yang telah diteapkan. Ada berbagai macam suhu yang bisa digunakan untuk dicari cepat rambat bunyi yang tentunya berbeda dan bervariasi serta diharapkan lebih memudahkan mahasiswa dalam memahami pokok bahasan tesebut. Telah dibuat alat eksperimen untuk menentukan cepat rambat bunyi di udara pada variasi suhu dengan memanfaatkan perangkat lunak Audacity dan Logger Pro. Metode yang digunakan adalah regresi linier. Hasil penelitian menunjukkan bahwa cepat rambat bunyi di udara bergantung pada suhu. Hal ini ditunjukkan oleh kurva suhu terhadap cepat rambat bunyi dengan $\mathrm{R}^{2}=0,992$. Dengan demikian maka diketahui bahwa semakin tinggi suhu maka semakin besar nilai cepat rambat bunyi.
\end{abstract}

Kata Kunci : Cepat rambat bunyi; variasi suhu; Logger Pro; Audacity 


\begin{abstract}
There is subject matter sounds particularly in experiments quickly creep, generally used at a temperature of $25^{\circ} \mathrm{C}$ that has been diteapkan. There is a wide range of temperatures that can be used to look for quick sound vines certainly different and varied and is expected to further facilitate students in understanding the subject matter are. Experimental tools have been created to determine quickly creep the sound in the air at the temperature variations by utilizing the software Audacity and Logger Pro. The method used is a linear regression. The results showed that the vines fast sound in the air depends on temperature. This is shown by the curve of temperature against fast sound with vines $R^{2}=0,992$. Thus it is known that the higher temperature then the greater the value of the vines fast sound.
\end{abstract}

Keywords : quickly creep; temperature variations; Logger Pro; Audacity

\section{Pendahuluan}

Bunyi merambat dalam bentuk gelombang[1]. Gelombang bunyi merupakan salah satu contoh gelombang mekanis longitudinal. Pada saat gelombang merambat di udara, elemen-elemen udara bergetar sehingga menimbulkan perubahan kerapatan dan tekanan disepanjang arah perambatan gelombang. Apabila sumber gelombang bunyi bergetar secara sinusoidal yang mempunyai frekuensi, amplitudo, dan panjang gelombang tertentu. Bunyi merambat dari sumber bunyi melalui medium dan membutuhkan waktu. Dan bunyi memiliki kecepatan merambat yang bisa ditentukan[2]. Bunyi termasuk gelombang mekanik. Akibatnya bunyi hanya dapat merambat melalui medium seperti : zat padat, cair, dan
Bunyi tidak dapat merambat melalui medium ruang hampa udara (vakum).

Cepat rambat bunyi bergantung pada sifat-sifat medium. Pada umumnya, cepat rambat bunyi pada medium padat lebih besar dari pada medium cair atau gas[3]. Cepat rambat bunyi terbesar dalam zat padat, kemudian dalam ratarata zat cair, dan terkecil dalam gas. Cepat rambat bunyi secara teoritik dapat dihitung dengan persamaan. Cepat rambat bunyi dari eksperimen dengan cara pengukuran cepat rambat bunyi di suatu medium yang telah diukur dengan fenomena resonansi dalam sebuah batang besi dan nilai panjang frekuensi dicatat dalam tampilan pada mikrokomputer dengan perangkat lunak [4].

Penelitian pengukuran cepat rambat 
bunyi di udara dengan bebasis komputer dengan perangkat lunak Audacity merupakan salah satu software analisis audio yang dapat merekam dan mencatat dua sinyal yang masuk melalui microphone dan mempunyai ketelitian pengukuran waktu 0,001 sekon (satu milisekon). [5]. Bunyi merambat dalam bentuk gelombang[1]. Gelombang bunyi merupakan salah satu contoh gelombang mekanis longitudinal. Pada saat gelombang merambat di udara, elemen-elemen udara bergetar sehingga menimbulkan perubahan kerapatan dan tekanan disepanjang arah perambatan gelombang. Apabila sumber gelombang bunyi bergetar secara sinusoidal yang mempunyai frekuensi, amplitudo, dan panjang gelombang tertentu. Bunyi merambat dari sumber bunyi melalui medium dan membutuhkan waktu. Dan bunyi memiliki kecepatan merambat yang bisa ditentukan[2]. Bunyi termasuk gelombang mekanik. Akibatnya bunyi hanya dapat merambat melalui medium seperti : zat padat, cair, dan gas. Bunyi tidak dapat merambat melalui medium ruang hampa udara (vakum).

Cepat rambat bunyi bergantung pada sifat-sifat medium. Pada umumnya, cepat rambat bunyi pada medium padat lebih besar dari pada medium cair atau gas[3]. Cepat rambat bunyi terbesar dalam zat padat, kemudian dalam rata-rata zat cair, dan terkecil dalam gas. Cepat rambat bunyi secara teoritik dapat dihitung dengan persamaan. Cepat rambat bunyi dari eksperimen dengan cara pengukuran cepat rambat bunyi di suatu medium yang telah diukur dengan fenomena resonansi dalam sebuah batang besi dan nilai panjang frekuensi dicatat dalam tampilan pada mikrokomputer dengan perangkat lunak [4].

Penelitian pengukuran cepat rambat bunyi di udara dengan bebasis komputer dengan perangkat lunak audacity. Audacity merupakan salah satu software analisis audio yang dapat merekam dan mencatat dua sinyal yang masuk melalui microphone dan mempunyai ketelitian pengukuran waktu 0,001 sekon (satu milisekon). [5]

Cepat rambat bunyi disamping gelombang longitudinal dan gelombang transversal, dikenal juga gelombang mekanik dan gelombang elektromagnetik. Besar fisis yang merupakan karakteristik dari peristiwa gelombang adalah panjang gelombang $(\lambda)$. Hubungan antara cepat rambat gelombang $(v)$, frekuensi $(f)$, dan panjang gelombang $(\lambda)$ dinyatakan oleh persamaan :

$$
V=\lambda f
$$

Bunyi adalah sebuah gelombang longitudinal yang terjadi karena perapatan dan perenggangan dalam suatu medium. Gelombang bunyi biasanya berjalan menyebar ke semua arah dari sumber bunyi dengan amplitudo yang bergantung pada arah dan jarak dari sumber. Secara 
teoritis cepat rambat bunyi pada medium udara dengan suhu $20^{\circ} \mathrm{C}$ sebesar $344 \mathrm{~m} /$ s.[6]

Cepat rambat (laju) gelombang bunyi seperti laju pada tali, juga bergantung pada sifat medium. Untuk gelombang bunyi dalam fluida seperti udara atau air, cepat rambat $v$ didapat dari

$$
v=\sqrt{\frac{B}{\rho}}
$$

Dengan $\rho$ adalah rapat keseimbangan (massa jenis) dan $B$ adalah modulus limbak (modulus bulk). Modulus bulk adalah rasio tekanan terhadap perubahan fraksional volume sebuah benda

$$
B=\gamma P
$$

Untuk gelombang bunyi merambat pada suatu batang padat modulus limbak diganti dengan modulus young $Y$

$$
v=\sqrt{\frac{Y}{\rho}}
$$

Untuk gelombang bunyi dalam gas seperti udara, untuk menentukan cepat rambat bunyi di gas. Diturunkan dari cepat rambat bunyi pada fluida, yang modulus Bulk $B$ dan kerapatan $\rho$ dapat digunakan untuk mencari cepat rambat bunyi dalam gas. Modulus limbak berbanding lurus dengan tekanan, yang dengan sendirinya sebanding dengan kerapatan $\rho$ dan temperature $T$.

Persamaan (2) ekivalen dengan

$$
v=\sqrt{\frac{B}{\rho}}=\sqrt{\frac{\gamma P}{\rho}}
$$

Kerapatan $\rho$ dihubungkan dengan jumlah mole $n$ dan molekuler $M$ oleh .

\section{Dengan}

$$
\rho=\frac{m}{v}=\frac{n M}{V}
$$

menggunakan gas ideal,

$$
P V=n R T
$$

Jadi kerapatan suatu gas ideal

$$
\rho=\frac{n M}{V}=\frac{n M}{\left(\frac{n R T}{P}\right)}=\frac{P M}{R T}
$$

dengan menggabungkan persamaan (6) dengan persamaan (5) didapat

$$
v=\sqrt{\frac{\gamma R T}{M}}
$$

jika suatu persamaan $T=T_{0}+t$, dengan $T_{0}=273,15 \mathrm{~K}$ dan didapat

$$
v=\left(\frac{\gamma R T_{0}}{M}\right)^{\frac{1}{2}}+\frac{1}{2}\left(\frac{\gamma R}{M T_{0}}\right)^{\frac{1}{2}} t
$$

Dengan persamaan ini, $T$ merupakan temperatur mutlak yang di ukur dengan kelvin. Konstanta $R$ adalah konstanta gas universal, yang mempunyai nilai 
konstanta gas universal, yang mempunyai nilai $R=8,314 \mathrm{~J} / \mathrm{mol} . \mathrm{K}$ dan konstanta $M$ adalah massa molar gas dan $\gamma$ merupakan konstanta yang bergantung pada jenis gas, untuk udara mempunyai nilai 1,4 [7].

Laju gelombang bunyi bergantung pada sifat medium penghantarnya. Medium udara, air, zat padat dan suhu akan menghasilkan cepat rambat bunyi yang berbeda-beda. Suhu udara yang lebih panas atau lebih dingin mempengaruhi kecepatan bunyi di udara. Di udara, pada suhu $0^{\circ}$ dan tekanan 1 atm kecepatan bunyi di udara sebesar $330 \mathrm{~m} /$ s. Laju bunyi di udara akan bertambah sebesar $0,5 \mathrm{~m} / \mathrm{s}$ untuk tiap kenaikan suhu $1{ }^{\circ} \mathrm{C}$. Contohnya, laju bunyi di udara pada suhu $10^{\circ} \mathrm{C}$ adalah $331 \mathrm{~m} / \mathrm{s}$. Cepat rambat bunyi bergantung pada dua hal :

a. Jenis medium

Udara merupakan medium yang paling sering dilalui gelombang bunyi. Zat cair dan zat padat merupakan penghantar yang lebih baik dari udara sebagai partikel-partikel di dalam zat cair atau zat padat saling mempengaruhi lebih kuat daripada partikel-partikel udara.

b. Suhu medium

Pada saat suhu zat meningkat, molekul-molekul bergerak lebih cepat sehingga frekuensi tumbukan antar partikel lebih banyak. Meningkatnya tumbukan molekul ini akan lebih banyak memindahkan energi dalam waktu yang lebih singkat. Ini memungkinkan gelombang bunyi berpindah lebih cepat [8].

Tabel.1 Cepat Rambat Bunyi Pada Material Gas [9]

\begin{tabular}{|c|c|}
\hline Material Gas & $\begin{array}{c}\text { Cepat rambat bunyi } \\
(\mathbf{m} / \mathbf{s})\end{array}$ \\
\hline Udara $\left(0^{\circ} \mathrm{C}\right)$ & 330 \\
\hline Udara $\left(10^{\circ} \mathrm{C}\right)$ & 331 \\
\hline Udara $\left(15^{\circ} \mathrm{C}\right)$ & 340 \\
\hline Udara $\left(20^{\circ} \mathrm{C}\right)$ & 344 \\
\hline Hidrogen $\left(0^{\circ} \mathrm{C}\right)$ & 1286 \\
\hline $\begin{array}{c}\text { Hidrogen }\left(20^{\circ}\right. \\
\mathrm{C})\end{array}$ & 1330 \\
\hline Helium $\left(20^{\circ} \mathrm{C}\right)$ & 999 \\
\hline Oksigen $\left(0^{\circ} \mathrm{C}\right)$ & 317.2 \\
\hline
\end{tabular}

\section{Bahan dan Metode}

Penelitian ini dilakukan dengan cara pengamatan dan pengukuran secara langsung. Data yang diperoleh adalah data yang bersifat kuantitatif. Namun demikian untuk lebih memperjelas, nantinya data tersebut juga akan didekripsikan secara kualitatif. Selain itu, data yang diperoleh akan dianalisis mengguanakan grafik hubungan antara besarnya cepat rambat bunyi dengan variasi suhu.

Untuk mendukung proses pelaksanaan penelitian tersebut, diperlukan media dan alat penelitiannya. Media dan alat penelitian itu adalah sebagai berikut: 


\subsection{Alat dan bahan penelitian}

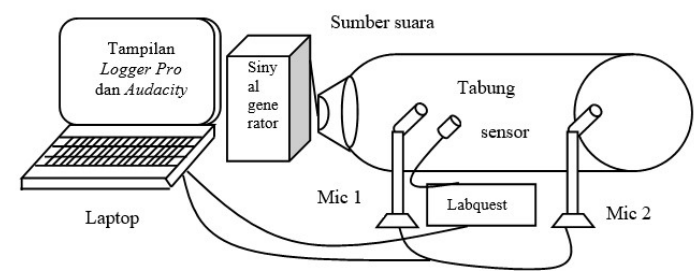

(a)

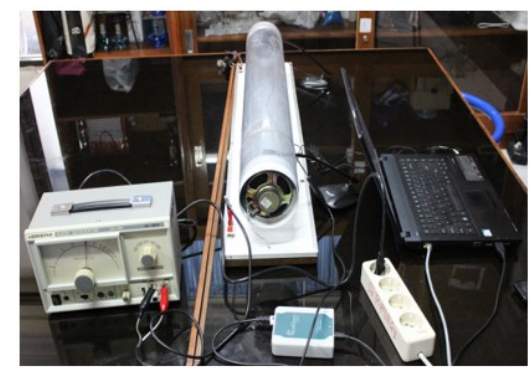

(b)

Gambar 1. (a). Desain alat, dan (b). Foto alat

Dalam penelitian ini digunakan peralatan yang terdiri dari perangkat lunak.

a. Perangkat keras

Perangkat keras yang digunakan dalam penelitian ini terdiri dari:

1. Laptop, digunakan untuk menerjemahkan hasil tracking dari pembacaan Audacity dan Logger pro yang sekaligus sebagai pengolahan data. Laptop yang digunakan adalah acer seri travelmate 47502 dengan processor intel ${ }^{\circledR}$ Pentium ${ }^{\circledR}$ serta sistem operasi windows 7 Home Premium.

2. Microphone, digunakan untuk menangkap suara yang dihasilkan dari sumber suara.
2. Mika tebal yang dibentuk tabung, yang digunakan untuk memasang komponen-komponen yang lainnya.

3. Sumber suara (audio generator), digunakan untuk menghasilkan suara.

4. Speaker, digunakan sebagai penerus suara dari audio generator.

5. Sensor suhu, digunakan untuk menangkap suhu yang berada dalam alat penelitian.

6. Labquest, digunakan untuk transduser penerima sinyal dari sensor dan diolah sebagai sinyal analog ke digital.

b. Perangkat lunak

\section{Logger Pro}

Logger Pro merupakan software yang digunakan untuk menganalisis bentuk kurva yang ditampilkan melalui layar utama dari Logger Pro. Selain digunakan untuk menganalisis bentuk kurva, Logger Pro juga dapat digunakan untuk menganalisis video dan gambar. Penggunaan software dalam penelitian ini digunakan untuk mentracker. Logger Pro juga memiliki fitur-fitur yang dapat digunakan untuk tracking sebuah video yaitu adanya pengaturan skala, pengaturan perpotongan arah sumbu $x y$, serta pengaturan standar panjang objek. Selain itu, titik-titik hasil tracking dapat disesuaikan dengan bentuk 
tampilan gelombang yang akan ditracking serta memiliki kurva untuk pilihan eksponensial [10].

\section{Audacity}

Audacity adalah software editor digital audio merupakan aplikasi untuk merekam suara atau bunyi. Yang merupakan perangkat lunak komputer dan tersedia untuk Windows, Mac OS X, Linux dan sistem operasi lain. Software ini dapat digunakan untuk menganalisis frekuensi bunyi yang terekam dengan bantuan microphone. Audacity merupakan freeware program atau berlisensi gratis yang dapat dicari di internet dengan me-download-nya. Audacity mengalami berbagai perbaikan demi kesempurnaan dan tampilan terbaru saat ini adalah audacity 2.0.5 [11].

\subsection{Prosedur Penelitian}

1. Alat dan bahan percobaan disiapkan.

2. Alat eksperimen dirangkai sesuai gambar 1.b.

3. Jarak kedua microphone ditentukan.

4. Varisai suhu yang sudah ditentukan.

5. Nyalakan laptop dan di buka program audacity yang telah terinstal.

6. Tipe saluran microphone, diatur serta pilih external microphone 2 (stereo) recording. Pada sumber bunyi pilih speaker/Hp.
7. Aplikasi logger pro yang telah terinstal dioperasikan.

8. Time based diatur dengan memilih menu experiment pada software logger pro, pilih data collection pada length isi 1800 second, sampling rate 1 sample/second.

9. Sumber suara diatur dengan frekuensi yang telah ditetapkan sebesar 30x10 Hz.

10. Tombol collect $\mid \nabla$ collect ditekan pada logger pro untuk memulai pengukuran suhu.

11. Suhu $15{ }^{\circ} \mathrm{C}$ digunakan, lakukan pengambilan data dengan mengklik tombol rekam - pada audacity. Kemudian tekan tombol play

12. Pada player, maka bunyi akan direkam pada audacity dan jika sudah tekan tombol stop $\bullet$ pada audacity.

13. Data hasil rekaman audacity di simpan di folder.

\section{Hasil dan Pembahasan}

Hasil percobaan yang dilakukan pada penelitian ini sesuai dengan prosedur langkah kerja yang telah ditetapkan dengan memvariasi suhu, maka didapat hasilnya sebagai berikut : 


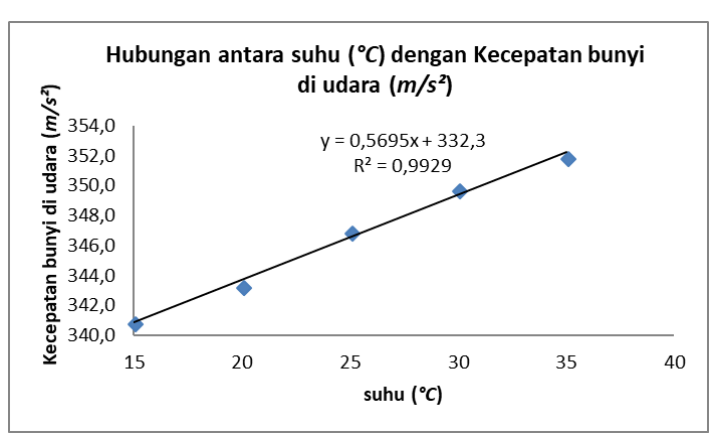

Gambar 2. Hubungan antara variasi suhu $\left({ }^{\circ} \mathrm{C}\right)$ dengan kecepatan $(v)$.

\section{Simpulan}

Berdasarkan gambar 2. grafik hubungan antara variasi suhu dengan kecepatan bunyi di udara didapat grafik linier, hal ini menunjukkan bahwa kecepatan bunyi di udara berbanding lurus dengan besar nilai suhu. Hal ini dapat dilihat dari nilai $\mathrm{R}^{2}=0,992$.

\section{Ucapan Terimakasih}

Kepada dosen pembimbing dan rekanrekan yang sudah mendukung penelitian ini.

\section{Referensi}

1. Ishafit. 2012. Teknologi Informasi dan Komunikasi Dalam Pembelajaran Fisika: Komputerisasi Eksperimen Bunyi Berbasis Soundcard Laptop. Final Prosiding Seminar Nasional Fisika, No.201219.

2. Velasco, S., Román, F. L., González, A., \& White, J. A. (2004). A computer-assisted experiment for the measurement of the temperature dependence of the speed of sound in air. American Journal of Physics, 72(2), 276-279.

3. Young dan Freedman, Roger A. 2002. Fisika Universitas Edisi ke sepuluh Jilid 1. 2002. Jakarta: Erlangga.

4. Supriyanto. 2006. Fisika SMA Untuk SMA Kelas XII. Jakarta: Erlangga.

5. Young dan Freedman, Roger A. 2003. Fisika Universitas Edisi ke sepuluh Jilid 2. Jakarta: Erlangga.

6. Tippler, P. A. (2001). Fisika untuk Sains dan Teknik jilid 1. Jakarta: Erlangga. Vernier. (20012)

7. http://softilmu.blogspot.com/2014/08/ gelombang-bunyi.html. Diunduh tanggal 23 Mei 2015.

8. http://

mulyawulansari.blogspot.com/2013/0 6/cepat-rambat-bunyi.html. Diunduh tanggal 23 Mei 2015

9. Audacity. (2013). "Audacity is free, open source, cross-plaform software for recording and editing sounds" dalam http://audacity.sourceforge.net. Diunduh tanggal 13 februari 2013.

10. http://

thufailpalestine.blogspot.com/2013/0 1/gelombang-bunyi.html. Diunduh tanggal 23 Mei 2015.

11. http://

zafiraafriza.blogspot.co.id/2012/10/ perambatan-gelombang-bunyi.html.

Diunduh tanggal 23 Mei 2015. 